\title{
Posting Workers as a New Model of Global Labour? Dilemmas of Economics, Politics and Ethics
}

\author{
Michal Trčka ${ }^{1,2, *}$ \\ 1 Institute of Technology and Business in České Budějovice, Faculty of Corporate Strategy, \\ Department of Human Resource Management, Okružní 517/10, 37001 České Budějovice, Czech \\ Republic \\ ${ }^{2}$ Technical University of Liberec, Faculty of Science, Humanities, and Education, Department of \\ Philosophy, Studentská 1402/2 46117 Liberec 1, Czech Republic
}

\begin{abstract}
.
Research background: Labour migration, i. e. the transnational movement of foreign workers on the European markets and their integration, is among the key topics of both Czech and European politics. I devote my paper to the regulation of work-related migration in a wider perspective of the global labour market in a specific type of labour migration ,posting workers“.

Purpose of the article: The paper focus on economic, political, and ethical problematic aspects of posting workers within the European Union in connection with the European Commission's revision of Directive 96/71/EC with an emphasis on posting workers to the Czech Republic.

Methods: I will to analyse the key patterns of the reactions and discourse strategies of selected Czech stakeholders regarding the proposal for a revision of Directive 96/71/EC, in particular that of selected government representatives. For this purpose, it will be used the method of discourse analysis (especially methods developed by Ruth Wodak).

Findings \& Value added: I would like to demonstrate, using the revision of Directive 96/71/EC as an example of new renovating models of global labour, as a part of the process of integration of the global market in the era of globalization, that the mechanism of posting workers creates a hybrid single European labour market, changes international relations, and contributes to the transnational flexibility of labour.
\end{abstract}

Keywords: discourse analysis; flexibility of labour; labour market; models of global labour; posting of workers

JEL Classification: $J 6 ; J 8 ; K 3 ; P 1 ; P 4$

\footnotetext{
${ }^{*}$ Corresponding author: 26604@mail.vstecb.cz
} 


\section{Introduction}

On March $8^{\text {th }}, 2016$, the European Commission presented a proposal for a revision of Directive 96/71/EC, which until then regulated the posting of workers in the European Union [1]. This proposal or in particular, some aspects of it, such as the principle of equal pay for equal work in the same country, have provoked a heated debate, not only between Members of the European Parliament but also between the European Union (EU) institutions and some Member States. Between submitting the proposal for the revision of Directive 96/71/EC in March 2016 and the final adoption of this revision in June 2018, for example, negotiations on the posting of workers were accompanied by discussions on more general issues such as protectionist measures in some Member States or convergence issues (with regard to wage, economic or social themes) and cohesion policies. The European Commission wanted the proposal to revise Directive 96/71/EC to respond to problematic phenomena, such as non-compliance with the regular posting of workers, which could serve to increase the profits of posting companies. Among some European Parliamentary Members, representatives of member states or employers' associations representatives, there are critical voices that Central and Eastern European countries will lose their competitiveness, that the directive promotes protectionist behaviour for older Member States, etc. Czech Republic representatives joined this criticism in the negotiations on the directive's revision.

As you can see from this brief list of selected problematic aspects regarding the posting of workers in the EU, this issue is not really just about amending one directive. This topic has been and still is connected with a number of other topics, questions and problems. "Posting workers" is a specific type of labour migration, a specific type of the transnational movement of foreign workers on the European markets and their integration, and the regulation of work-related migration in a wider perspective of the global labour market. This is the reason why the subject needs to be explored with a view to knowledge of the global context - the methodological approach reflected processes of globalization [2]. Recently, we can also reflect on posting workers related to the social and economic impacts of the pandemic on individual, national and global economy and question if the European labour market needs renovating in this way or if it is not a good concept.

I would like to demonstrate, using the revision of Directive 96/71/EC as an example of renovating global labour models, as a part of the global market integration process in the globalisation era, that the posted worker mechanism creates a hybrid single European labour market, and contributes to the transnational labour flexibility. This paper is based on research of my dissertation, which has not been published anywhere and is supplemented by an update of the new analysis from June 2018 to June 2020 .

\section{Methods}

The analysis is based on the methodological tradition and uses the Critical Discourse Analysis (CDA) approach. The main source for my own analysis is The DiscourseHistorical Approach (DHA), developed by Austrian linguist Ruth Wodak [3]. Wodak connects the analysis of discourses and texts with action, social field, current and historical context. This should provide a picture of how utterances are changing at a textualdiscursive, political and social level [4]. I will connect data with theoretical knowledge (especially in the political science and sociology fields).

I will analyse the key patterns of the reactions and discourse strategies of selected Czech stakeholders regarding the proposal for a revision of Directive 96/71/EC, particularly that of selected government representatives (focusing on Czech Republic Government representatives - Prime Minister in the given period, the Government Office, the Ministry 
of the Interior, the Ministry of Labour and Social Affairs, the Ministry of Foreign Affairs, the Ministry of Industry and Trade, the Ministry of Transport, the Czech Chamber of Commerce and the Czech-Moravian Trade Union Confederation).

The triangulation approach used by Wodak [5], which I also follow in this paper, is based on the concept of "context", which takes four levels into account: firstly, direct, linguistic or textual internal context (words surrounding a selected term/statement, etc., which help to determine meaning and create context), secondly the intertextual and interdiscursive relationship between statements, texts, genres and discourses, thirdly extralinguistic social/sociological variables and institutional frameworks of specific "context of the situation" - the use of Middle-Range Theory, fourthly the broader socio-political and historical contexts - the use of general theories.

In the analysis I combined work with primary and secondary sources, data collection and analysis, namely both qualitative data (qualitative analysis of texts) and quantitative data (e.g. using statistical data, basic information on labour migration, annual trends, etc.). I also worked with various types of texts and documents (legal norms, comments from individually selected actors, so-called policy documents, public statements, press releases, professional studies in the field of political science, sociology and other social science disciplines, etc.), which are related to posting workers.

\section{Results}

In the analysed period from March 2016 to June 2020, I recorded both the interconnection of some arguments or argumentation schemes for selected Czech stakeholders (see above), as well as a significant partial (in some types of argumentation and overall) diachronic change (development over time) discourses. However, the Czech Government representatives held a relatively uniform position in the European negotiations, so it was not necessary to distinguish positions between individual government representatives in a given time period.

In 2016, the Czech Republic Government was generally critical or negative of the European Commission's efforts to revise Directive 96/71/EC and in this respect defended a similar general position, which was also held by representatives of entrepreneurs and employers, as opposed to trade unions, who always supported the European Commission's proposal. The change only occurred in 2017, when the Czech Government focused on its comments on finding a compromise between member states and EU institutions, and began to recognise the issue of social dumping as a common problem for all member states, positively assessed some measures in the proposal to revise Directive 96/71/EC and was only critical in this respect against applying the same rules in the transport sector.

Throughout the analysed period, one of the most important applied discursive strategies was the formation of categorisation and polarisation of "we" and "they" categories. In all years, in the Czech Government statements, the "we" category was only used for all EU countries if it was a defence of free movement, internal market without barriers, etc. The "they" category, constructed by the Czech Government, underwent changes in the period. However, at all times, those who circumvent and abuse existing posting rules have been included under the "they" category. In 2016, this designation was used mainly for Western European companies, in 2017 this statement in relation to Western European companies was generally used for the transport sector and it was also used in the transport sector in 2018.

Regarding the analysis of the Czech Republic Government's arguments, the argumentation schemes completely lacked arguments focusing on the incompatibility of the given conduct with human rights. Furthermore, in the analysis of texts and argumentation methods, the use of several types of misleading arguments appeared. In 2016 and 2018, the 
use of ad hominem arguments appeared several times in the Czech Government's arguments, for example, in accusing Western European countries and companies of violating the rules of the current Directive 96/71/EC, which lacked specific examples or evidence for these allegations.

In connection with the negotiations on the revision of Directive 96/71/EC, the Czech Government pointed out that the diversity of Member States should be preserved and respected, the legislation and principles of subsidiarity and proportionality should be applied equally and the role of national parliaments strengthened. In this respect, negotiations on the rules for posting workers, in my view, could be linked to questioning the "traditional" concept of organising the political, economic and social sphere in a modern state through European integration, restructuring relations between states and other actors [6]. In my opinion, the fact that the negotiations on the revision of Directive $96 / 71 / \mathrm{EC}$ are a change in the sovereignty of the modern (European) state, but not its questioning that the modern state remains a politically important player in the case of deterritorialisation of its sovereignty, documents, for example, the setting of the implementation of Directive 2014/67/EU, which allowed the Czech Republic Government to adapt the implementation to Czech legislation.

In the case of the economic dimension, there has been a connection with the theory that individuals, social groups, whole localities or regions are united by transnational interdependence, but many actors are excluded by uneven geopolitical development, especially with regard to participation in shaping the transnational economy [7]. For example, the Czech Government pointed out that there was insufficient EU integration, which is reflected in differences in the political and economic spheres between old and new member states. The criticism from the Czech Government that the proposal to revise Directive 96/71/EC may be associated with threats to the competitiveness of small and medium-sized enterprises from economically weaker Member States, etc., then corresponded to the theory [8], that transnational capital mobility may undermine and disrupt territorial organisations and local or national economies must now adapt to the reality of this new decentralised and transnational capital mobility. However, the Czech government acted as a pro-European government and in my opinion assessed the economic dimension positively in the form of measures to strengthen the internal market and transnationalise the economy, which corresponds to the theory that the processes of deterritorialisation of a modern (European) state are perceived as a functional integration of internationally dispersed economic activities [9].

The Czech Republic Government did not oppose the posting of workers as such, but only against its new definition, i.e. against the new rules in the proposal for the revision of Directive 96/71/EC. The Czech Government did not perceive it as a problematic issue that posted workers are considered a "labour force", and therefore, the conditions of their work and life in the recipient countries are regulated within the free movement of services instead of free movement of people. On the contrary, recommendations aimed at further labour flexibility appeared in the Czech Government's texts, and the free movement of services was generally perceived as an allocation of human capital rather than as a source of uncertainty for workers and wage dumping. In its comments on the proposal for the revision of Directive 96/71/EC, the Czech government did not significantly reflect other problematic aspects of posting workers, such as violations of posted workers 'rights, barriers to enforcing posted workers' labour rights or the growth of the grey economy due to the involvement of various employment agencies. There was no indication in the analysed texts that the Europeanisation of labour markets suppresses the relationship between the state, its territory and citizens, which limits the collectivism of workers and their representation (e.g. through trade unions), i.e. that the posting mechanism undermines the concept of industrial citizenship [10]. For these and other reasons, I believe that the 
Czech Republic Government tended to support efforts to maximise the effectiveness of the internal market system's functioning, rather than, for example, protecting employees' rights.

\section{Discussion}

Although the posting of workers supports the change of state sovereignty and contributes to the increase of transnational labour flexibility, these phenomena were not ultimately assessed negatively by the Czech government. The Czech government's texts included recommendations aimed at making working hours and forms of work flexible. In my view, although it could be argued that the number of posted workers is low on an EU-wide average, the form of the rules on the posting of workers suggests, a deeper context, such as where the EU is heading in setting the rules for the internal market's functioning. In this respect, throughout the analysed period, the Czech Republic Government promoted the strengthening of the neoliberal space of the so-called free market.

According to Ninke Mussche, Vincent Corluy and Ivo Marx, the European market is not single [11]. Indeed, the high level of short-term mobility of services is more important in the European market than long-term labour migration and is subject to different rules, and therefore it is necessary to perceive a different hybrid single European labour market associated with short-term mobility of services from the single European labour market associated with free movement of labour. According to these authors, posting workers can be considered as one of the driving forces of the hybrid single European labour market. The posting of workers is not a problem simply because of the inequalities between old and new Member States, because posting workers affects all Member States. It is a popular form of economic migration, mainly due to the benefits it offers to employers and suppliers, but also to workers, mostly from so-called third countries, who do not need a traditional work permit to enter Member States and generally we can see that temporary work arrangements have increased $[12,13]$.

The posting of workers offers a number of problematic aspects (e.g. limited supply chain regulation and obstacles to trade union representation, or the manufactured uncertainty of employment and immigration status) [14], but the Czech Republic Government, in its efforts to regulate and balance the free movement of services and the protection of the rights and social interests of posted workers, emphasised the free market's freedom. In my opinion, the Czech government should reflect more on the protection of the rights and social interests of posted workers, because each state is responsible for what happens within its own jurisdiction, so it is also responsible for acceptable standards regarding working conditions in its territory and their observance [15]. Regarding the violation of the rules of posting of workers, the illegality of working hours was mainly punished by falsely posted workers who had to leave the Czech Republic territory, not their employers. If employers received fines for illegal employment, then on the other hand it can be stated that poor working conditions, wage evaluation, and the safety of posted workers were not significantly reflected, examined and punished by the Czech state institutions.

The interpretation of selected Czech government representatives on the specific manifestation of posting workers to the Czech Republic - Ukrainian workers through socalled Polish visas $[16,17]$ - was critical, but the critical assessment of this phenomenon did not play an important role in assessing the general posting mechanism (as a specific example of more general internal labour mobility EU), for which the Czech government emphasised its economic usefulness. Posting of workers could be included in the more general category of temporary labour migration and aLehmann, Hs part of the phenomenon of precarious labour [18]. The jobs of low-skilled posted workers (as well as other types of precarious work) are not full-fledged because they are short-term and temporary, may be 
associated with insufficient financial rewards, uncertain access to housing, low probability of social mobility, etc. [19]. In my opinion, not only in the case of posting workers, but in general in the case of labour migration, it is possible to observe their connection with labour deregulation [20,21].

On the one hand, the revision of Directive 96/71/EC succeeded in enforcing equal pay for equal work in the same place, which improved the position of posted workers, but on the other hand the posting mechanism contributes to labour flexibility, posted workers are only temporary workers, which it undermines their possible involvement in industrial citizenship, limits the collectivism of workers and their representation in bargaining or their labour rights.

\section{References}

1. European Commission (2016). Communication from the Commission to the European Parliament, the Council and the National Parliaments on the proposal for a Directive amending the Posting of Workers Directive, with regard to the principle of subsidiarity, in accordance with Protocol No 2. EUR-Lex.europa.eu. https://eurlex.europa.eu/legal-content/EN/TXT/PDF/?uri=CELEX:52016DC0505\&from=CS

2. Reiche, B.S., Lee, Y., Allen, D.G. (2018). Actors, Structure, and Processes: A Review and Conceptualization of Global Work Integrating IB and HRM Research. Journal of Management, 45(2), 359-383.

3. Wodak, R. (2001a). The discourse historical approach. In Wodak, R., Meyer, M. (Eds.). Methods of Critical Discourse Analysis (63-94). London, New Delhi: SAGE.

4. Wodak, R. et al. (2009). The Discursive Construction of National Identity. Second edition. Edinburgh: Edinburgh University Press, 7-8.

5. Wodak, R. (2007). Critical Discourse Analysis. In Seale, C. (Eds.). Qualitative Research Practice (pp. 185-201). London: Sage.

6. Wagner, I. (2015). Posted Work and Deterritorialization in the European Union. A study of the German Construction and Meat Industry. Ph.D. Thesis. Jyväskylä: University of Jyväskylä, Jyväskylä Studies in Education, Psychology and Social Research, 26.

7. Cochrane, A., Pain, K.A. (2000). Globalizing Society? In D. Held (Eds.). A Globalising World? Culture, Economics, Politics (pp. 5-46). London, New York: Routledge.

8. Cauvet, P. (2011). Deterritorialisation, reterritorialisation, nations and states: Irish nationalist discourses on nation and territory before and after the Good Friday Agreement. GeoJournal, 76(1), 77-91.

9. Haidinger, B. et al. (2018). Enhancing Economic Democracy for Posted Workers. Brussels: Solidar.

10. Mussche, N., Corluy, V., Marx, I. (2017). How posting shapes a hybrid single European labour market. European Journal of Industrial Relations, 24(2), 441-459.

11. Boyce, A.S., Ryan, A.M., Imus, A.L., Morgeson, F.P. (2007). “Temporary Worker, Permanent Loser?" A Model of the Stigmatization of Temporary Workers. Journal of Management, 33(1), 5-29.

12. Meszmann, T.T. (2019). Snakes or Ladders? Job Quality Assessment among Temp Workers from Ukraine in Hungarian Electronics. Central and Eastern European Migration Review, 8(1), 75-93. 
13. Novitz, T., Andrijasevicz, R. (2020). Reform of the Posting of Workers Regime - An Assessment of the Practical Impact on Unfree Labour Relations. JCMS: Journal of Common Market Studies, 58(5), 1325-1341.

14. Carens, J.H. (2013). The Ethics of Immigration. Oxford: Oxford University Press.

15. Lehmann, H., Pignatti, N. (2018). Informal employment relationships and the labor market: Is there segmentation in Ukraine? Journal of Comparative Economics, 46(3), 838-857.

16. Gorny, A., Kaczmarczyk, P. (2018). A known but uncertain path: The role of foreign labour in Polish agriculture. Journal of Rural Studies, 64, 177-188.

17. Standing, G. (2011). The Precariat. London: Bloomsbury Academic.

18. Standing, G. (2015) A Precariat Charter. From denizens to citizens. London, New York: Bloomsbury, 16-22.

19. Wills, J. et al. (2010). The Necessary Connection: Labour Deregulation and International Migration. In Global Cities at Work: New Migrant Divisions of Labour (pp. 1-27). London: Pluto Press.

20. Rinz, K. (2020). Labor Market Concentration, Earnings, and Inequality. The Journal of Human Resources. Published online before print, October 12, 2020 